Anna Dymmel

Instytut Informacii Naukowej i Bibliotekoznawstwa Uniwersytet Marii Curie-Skłodowskiej w Lublinie e-mail: a.dymmel@poczta.umcs.lublin.pl

\title{
Współczesna książka dziecięco-młodzieżowa i media. Bestsellery fantasy i ich recepcja w polskiej mediosferze
}

DOI: http://dx.doi.org/10.12775/TSB.2017.027

STRESzCzENıE: Zagadnienie relacji współczesna książka dla dzieci i młodzieży a media należy obecnie do istotnych kwestii podejmowanych przez badaczy. W dyskusje na ten temat, z perspektywy bibliologii, włącza się monografia Michała Rogoża Fantastycznie obecne. Anglojęzyczne bestsellerowe cykle powieściowe dla dzieci i młodzieży we współczesnej polskiej przestrzeni medialnej. Autor analizuje popularne cykle z zakresu fantastyki, tj. Opowieści z Narnii Clve'a Staplesa Lewisa, Harry'ego Potter Jane K. Rowling, Zmierz Stephenie Meyer, Mroczne Materie Philipa Pulmana, Dziedzictwo Christophera Paoliniego i ich recepcję w tradycyjnych mediach i w polskojęzycznym Internecie. Niniejszy artykuł zawiera omówienie wspomnianej monografii, przedstawia główne tezy autora oraz wnioski i interpretacje.

SŁowA KLUCzowe: współczesna książka dla dzieci i młodzieży, fantasy, media, Internet, bestseller, czytelnictwo, recepcja, Harry Potter, Stephenie Meyer. 
odbiorcy, czytelnictwa i rynku wydawniczego autorstwa Michała Rogoża ${ }^{1}$. Rozprawa dobrze wpisuje się w dyskusje nad współczesną książką dla dzieci i młodzieży, a także obecnie szczególnie istotne zagadnienia relacji książka - inne media oraz funkcjonowania książki w przestrzeni medialnej ${ }^{2}$. Podjęty temat doskonale włącza się w dotychczasowe obszary zainteresowań badawczych autora. Stanowi naturalną konsekwencję i rozwinięcie badań skoncentrowanych m.in. nad książką dla najmłodszych i nastoletnich odbiorców oraz jej recepcją, szczególnie tytułów, które już na trwałe weszły do klasyki literatury dziecięcej i nadal są obecne w obiegu czytelniczym ${ }^{3}$. Należy podkreślić, że wspomniane klasyczne już pozycje (m.in. książki o Kubusiu Puchatku, cykl o Muminkach i inne) stały się także, wraz z rozwojem kultury audiowizualnej i multimedialnej, przedmiotem licznych twórczych intersemiotycznych przekładów odwołujących się niejednokrotnie do pozaliterackich doświadczeń odbiorców.

W omawianym przypadku autor podjął się badania popularnych cykli z gatunku fantastyki i ich recepcji w polskojęzycznej przestrzeni medialnej. Tym samym M. Rogoż stanął przed niełatwym zadaniem badania zjawisk dziejących się „tu i teraz”, przy tym zjawisk o dużej dynamice, złożonej i zmiennej strukturze, a jednocześnie, zwłaszcza wobec braku tak niezbędnego badaczowi dystansu czasowego, trudnych do jednoznacznego opisu i wyjaśnienia. Dlatego też, co warto podkreślić, wszelkie podejmowane próby analizy i naukowego wyjaśniania zacho-

${ }^{1}$ M. Rogoż, Fantastycznie obecne. Anglojęzyczne bestsellerowe cykle powieściowe dla dzieci i młodzieży we współczesnej polskiej przestrzeni medialnej, Kraków: Wydawnictwo Uniwersytetu Pedagogicznego, 2015, 284 s. (Prace Monograficzne; nr 748). ISBN 978-83-7271-966-9.

${ }^{2}$ Porównaj m.in. artykuły w tomach: W kręgu kultury czytelniczej dzieci i młodzieży, pod red. M. Antczak, A. Walczak-Niewiadomskiej, Łódź 2015; Ksiq̨żki w życiu najmłodszych, pod red. M. Antczak, A. Walczak-Niewiadomskiej, Łódź 2015; ponadto L. Sadzikowska, Mapa współczesnych badań nad książkq dziecięco-młodzieżowq, [w:] Literatura dla dzieci i młodzieży, pod red. K. Tałuć, Katowice 2017, s. 360-378.

3 M.in. M. Rogoż, Internet Information Space of the Polish Edition of "Histories inedites du Petit Nicholas”, „Zagadnienia Informacji Naukowej” 2010, nr 1, s. 71-83; tenże, Czas i przestrzeń w cyklu powieściowym Joanne K. Rowling o Harrym Potterze, „Literatura i Kultura Popularna" 2010, t. 16, s. 59-75; tenże, Muminki Tove Jansson na polskim rynku wydawniczym, „Toruńskie Studia Bibliologiczne” 2011, nr 4, s. 43-67; tenże, Kubuś Puchatek jako bohater wielu pokoleń. Z dziejów recepcji arcydzieła Alana Aleksandra Milne'a na polskim rynku wydawniczym, [w:] Młody odbiorca w kręgu lektur pożytecznych i szkodliwych, pod red. K. Heskiej-Kwaśniewicz, współpraca S. Gajownik, Katowice 2012, s. 59-75. 
dzących procesów z obszaru szeroko pojętej kultury współczesnej należy uznać za szczególnie ważne.

Rozprawa, jak autor podaje we Wstępie, jest próbą opisu i wyjaśnienia funkcjonowania książki współczesnej w dobie konwergencji mediów i w kontekście szeroko pojętej mediosfery. Michał Rogoż skupił się na wybranych przykładach z kręgu fantastyki adresowanej do młodego odbiorcy: Opowieści z Narnii Clive'a Staplesa Lewisa, cykl o Harrym Potterze Jane K. Rowling, Zmierzch Stephenie Meyer oraz Mroczne materie Philipa Pullmana i Dziedzictwo Christophera Paoliniego. Wybrane tytuły ukazywały się na rynku wydawniczym w wersji oryginalnej i w polskich przekładach w różnym czasie, niezależnie jednak od czasu edycji wkrótce po pojawieniu się na rynku zwykle trafiały na światowe lub krajowe listy bestsellerów. Wybrane przykłady wytyczają konstrukcję książki. Składa się ona z czterech rozdziałów, z których każdy poświęcony jest omówieniu recepcji wybranego cyklu powieściowego w Polsce i polskojęzycznej przestrzeni medialnej, przy czym odbiór powieści Mroczne materie i Dziedzictwo omówiony został łącznie w ostatnim czwartym rozdziale. Autor konsekwentnie analizuje recepcję wydawniczą wybranych utworów, tj. chronologię edycji, przekłady na język polski, szatę graficzną, następnie adaptacje i inne okołoksiążkowe wydawnictwa, uwzględnia filmy i gry komputerowe inspirowane wybranymi tytułami, a stanowiącymi dzisiaj nieodzowny element kultury multimedialnej oraz gadżety. Kluczowym obszarem analizy była obecność tematyki związanej z różnorodnymi formami istnienia wybranych przekazów w prasie codziennej i wybranych tygodnikach społecznych oraz funkcjonowanie w przestrzeni Internetu. Rozłożenie akcentów w poszczególnych przypadkach wiązało się m.in. ze zróżnicowanym czasem premiery polskich przekładów na rynku wydawniczym i kolejnych wydań, istotny wpływ, co oczywiste, wywierała korelacja czasu edycji z rozwojem sieci i technologii. Pierwszy polski przekład Opowieści z Narnii pojawił się pod koniec epoki PRL w 1985 r., następnie na fali zainteresowania fantastyką wydawnictwa Media Rodzina i Świat Książki kilkakrotnie publikowały kolejne edycje w latach 90. XX w. i pierwszej dekadzie lat dwutysięcznych. Z czasem pojawiły się kontynuacje i nawiązania, tj. filmy, gry komputerowe, chociaż nie powstały gry sieciowe inspirowane tematyką cyklu. Natomiast w mniejszym stopniu utwór zachęcał do tworzenia fanfików, za to pojawiały się liczne wpisy poświęcone Opowieściom z Narnii na pry- 
watnych blogach ${ }^{4}$. Jak słusznie skonstatował autor, „utwór ten przeszedł ewolucję od subtelnej książki dziecięcego pokoju do multimedialnego produktu współczesnej kultury" (s. 72). Świadectwem recepcji przez dłuższy czas pozostawały wypowiedzi i dyskusje prasowe. Toczącym się polemikom na łamach wybranych dzienników i czasopism (m.in. „Gazeta Wyborcza”, „Rzeczpospolita”, „Polityka”, „Newsweek”), o czym poniżej, towarzyszyły wypowiedzi również w prasie katolickiej, gdzie krytycy podkreślali walory humanistyczne i literackie utworu oraz akcentowali wartości chrześcijańskie. W miarę rozwoju sieci dyskurs przenosił się do świata wirtualnego, przede wszystkim wypowiedzi pojawiały się na znanych portalach lubimyczytac.pl, biblionetka.pl, merlin.pl, filmweb.pl, gry-online.pl, aktywne były społeczności skupione wokół forów internetowych i blogów (s. 70).

Pozostałe tytuły pojawiły się na rynku wydawniczym pod koniec lat 90. XX wieku lub w początkach nowego tysiąclecia. Zarówno cykl o Harrym Potterze, jak i Zmierzch stanowiły niewątpliwie szczególnie istotne wydarzenie z perspektywy rynku wydawniczego i medialnego ${ }^{5}$. Wielokrotnie obecne na światowych i polskich listach bestsellerów, inspirowały do tworzenia kolejnych produktów medialnych, wzbudziły także wyjątkowe poruszenie w mediach, co objawiało się zainteresowaniem prasy kolorowej i opiniotwórczej oraz szczególną obecnością tematyki w sieci. Z pewnością Harry Potter zyskał status dobrze rozpoznawalnej marki, której sprzedaż podlegała procesowi licencyjnemu (s. 73-74). Cykl o Harrym Potterze i inne pochodne przekazy dzięki umiejętnej strategii marketingowej, fabule trafiały w gusta licznych odbiorców, wzbudziły także dyskusje natury ideologicznej. Zainteresowanie umiejętnie stymulowane przez rynek wydawniczy i medialny zaowocowało także twórczością fanowską. Obok krótkich wypowiedzi na blogach, forach, portalach pojawiały się licznie fanfiki. Podobnie w przypadku Zmierzchu S. Meyer starano się powtórzyć sukces opowieści o małym czarodzieju, wykorzystując sprawdzone mechanizmy reklamy i strategie budowania multimedialnego produktu. Polskie edycje pojawiały się w latach

${ }^{4}$ P. Siuda, Fanfiction - przejaw medialnych fandomów, [w:] Człowiek a media. Obserwacje - wizje - obawy, pod red. W. Gruszczyńskiego, A. Hebdy, Warszawa 2007, s. 143-157.

5 M.in. M. Kruk, Fenomen popularności małego czarodzieja. Harry Potter Joanne K. Rowling i młodzi odbiorcy, [w:] Bestsellery, literatura popularna, odbiorcy, pod red. A. Dymmel, Lublin 2009, s. 11-28. 
2007-2013, towarzyszyły im adaptacje filmowe (tom I w 2008 r.), gry, również w opcjach na telefon (głównie dla kobiet), gadżety w postaci m.in. portfeli, torebek, długopisów, zeszytów, ponadto zabawki firmy Mattel i stroje dla lalek. Nieodzowny element stanowiły książki okołotematyczne. Wydawnictwa, korzystając z mody na historie o nastoletnich wampirach, proponowały czytelnikom serie inspirowane wspomnianą tematyką, np. „Czytaj po Zmierzchu” Wydawnictwa Dolnośląskiego. Ponadto powstawały rodzime trylogie nawiązujące do motywów powieści grozy oraz wydawano inne powieści S. Meyer, albumy poświęcone filmom, przewodniki po treści sagi, komiksy i biografie autorki. Oczywiście cyklowi towarzyszyła ożywiona recepcja w prasie i w przestrzeni wirtualnej, chociaż nie przyćmiła rozgłosu towarzyszącego opowieści o Harrym Potterze. Poza licznymi wypowiedziami na temat książek, filmów, postaci na forach i portalach zainteresowaniu towarzyszyły amatorskie reinterpretacje niekiedy dość swobodnie nawiązujące do pierwowzoru.

Nieco inaczej wyglądała w Polsce popularność dwóch pozostałych tytułów. Jak dowodzi autor, ponadprzeciętna sprzedaż części Dziedzictwa nie wprowadziła tytułu na polskie listy bestsellerów, nie spowodowała wysypu tytułów okołoksiążkowych. Adaptacja filmowa miała w Polsce premierę w grudniu 2007 r., ponadto przygotowano grę fabularną. Jednak utwór i inne produkty nie spowodowały szczególnego ożywienia w prasie, mniejsze zainteresowanie wzbudził także utwór Paoliniego w polskojęzycznej sieci, co przejawiało się zarówno mniejszą obecnością stron komercyjnych, jak i słabo widoczną spontaniczną aktywnością fanowską. Również recepcja książki Mroczne materie Philipa Pullmana w polskiej wersji wydanej przez oficynę MAG nie przybrała tak spektakularnych form, jak miało to miejsce w przypadku powieści o Harrym Potterze.

Należy zwrócić uwagę, że autor, badając społeczno-kulturowe istnienie wybranych transmedialnych produktów funkcjonujących na rozmaitych platformach medialnych (książka, film, gry komputerowe, gadżety itd.), umiejętnie wykorzystał różne perspektywy badawcze: bibliologiczną i informatologiczną, prasoznawczą, komunikacji społecznej, sięgnął także do wybranych kategorii literaturoznawczych i medioznawczych. Autor umiejętnie zastosował w pracy liczne metody: metodę księgoznawczą, prasoznawczą, metody i narzędzia webometryczne przydatne w śledzeniu ruchu sieciowego. 
Z pewnością istotne znaczenie dla dokonanych ustaleń miał dobór materiałów źródłowych. Podejmując powyższy temat, Michał Rogoż musiał zmierzyć się z obfitością zasobów dostępnych w mediach, rządzących się nieco odmiennymi regułami, specyficznymi z uwagi na kanał komunikacyjny i swoisty sposób utrwalania i transformacji rzeczywistości. Sięgnął do zasobów prasowych i Internetu, w istocie zróżnicowanych z uwagi na nadawców podlegających różnym mechanizmom regulacyjnym, które w konsekwencji wytyczają orientację dyskursywną nadawcy. Dokonał nieco subiektywnego, chociaż uzasadnionego przynależnością do pism opinii, wyboru tytułów prasowych. Skupił się przede wszystkim na materiałach zamieszczanych w dziennikach: „Gazeta Wyborcza”, „Rzeczpospolita”, „Super Express” oraz pismach opinii „Polityka” i,Wprost”. Niemniej w analizie jakościowej słusznie zwrócił uwagę także na wypowiedzi z innych mediów, w tym mediów katolickich, przede wszystkim z prasy, na łamach której ukazywały się wypowiedzi o wybranych utworach pisane z perspektywy etyki chrześcijańskiej, co w pewnym stopniu pozwoliło ukazać zróżnicowanie recepcji wybranych utworów.

W przypadku gromadzenia materiałów z sieciosfery wykorzystał perspektywę najpopularniejszej przeglądarki Google i stron najczęściej odwiedzanych, co w pewnym sensie prezentuje dyskurs głównego nurtu, ale też dobrze oddaje kierunki zainteresowań odbiorców. Autor dobrze panuje nad bogactwem materiałów (zgromadził co najmniej kilka tysięcy wypowiedzi), nie dając się ponieść niekiedy zgubnej chęci zaprezentowania większości szczegółowych faktów, chociaż czasami lakoniczne konstatacje nie pozwalają do końca na poznanie niuansów recepcji. Dodam, że zalety i ograniczenia zasobów sieciowych, w tym ich znaczenie jako źródła danych dla badań społecznych, były już przedmiotem rozważań np. socjologów, z pewnością jest to temat istotny i nadal aktualny ${ }^{6}$. Zastosowanie w omawianej pracy metod oraz narzędzi bibliometrycznych i webometrycznych sprzyjało ukazaniu wymiaru ilościowego badanych zjawisk, nie zabrakło jednak jakościowych analiz zmierzających do wyjaśnienia fenomenu popularności wybranych tytułów.

${ }^{6}$ K. Krzysztofek, BIG DATA SOCIETY. Technologie samozapisu i samo pokazu. Ku humanistyce cyfrowej. „Kultura i Historia” [online] 2012, nr 21 [dostęp 30 września 2017]. Dostępny w World Wide Web: http://www.kulturaihistoria.umcs.lublin.pl/archives/3626. 
Wyznaczników owej popularności Michał Rogoż słusznie upatruje w samym tekście, jego walorach estetycznych, ideowych, odwoływaniu się do schematów i stereotypów typowych dla kultury popularnej, wpisujących się $\mathrm{w}$ archetypiczne myślenie o świecie, wydatnie wspomaganych przez instrumentarium współczesnej kultury multimedialnej. Drugim istotnym czynnikiem są sami odbiorcy o zmiennych gustach i niestałych zainteresowaniach, wytyczający społeczne granice obiegu książki i kultury, zręcznie stymulowani lub wręcz kreowani przez komercyjny rynek wydawniczy i medialny.

W obszarze recepcji rysuje się wyraźny podział na znawców (krytyków) i nie do końca nazwanych w monografii nieprofesjonalistów, których „horyzont oczekiwań” i kompetencje (jak znaczne?) faktycznie decydują o komercyjnym powodzeniu przedsięwzięcia. Jednocześnie odmienne sposoby odczytania, stopniowalne zaangażowanie odbiorców, wyrażone m.in. poprzez aktywność w sieci (i poza nią), pozwalają dostrzec wśród nich zróżnicowane kategorie. Należy też zauważyć, czego również autor jest świadomy, że wokół szeroko pojętej fantastyki szczególnie chętnie tworzą się społeczności fanowskie zaliczane do subkultur konsumpcji. Uzupełniając i wychodząc już poza obszar bibliologii i informatologii, dla objaśnienia przyczyn popularności i mechanizmów funkcjonowania poszczególnych produktów medialnych warto zwrócić szczególną uwagę na ten rodzaj odbiorców. Fani stanowią przedmiot oddzielnych badań socjologicznych i medioznawczych ${ }^{7}$. Jak twierdzi socjolog Piotr Siuda, dzisiejsze firmy z branży rozrywkowej, dążąc do sukcesu komercyjnego, starają się o stworzenie oddanej grupy nabywców/odbiorców pracujących na rzecz danego tekstu kultury ${ }^{8}$. Niewątpliwie Sieć 2.0 spowodowała, że dla producentów szczególnie ważny stał się już nie bierny odbiorca, ale aktywny, chociaż nie zawsze kompetentny twórca amatorskich opowiadań, filmików, gier, grafiki i stron WWW oraz kreator nowych trendów. Ponadprzeciętni odbiorcy i zarazem twórczy nadawcy intensyfikujący swój odbiór poprzez amatorską produkcję opartą na

7 M.in. H. Jenkins, Textual Poachers. Television Fans and Participatory Culture, New York 1992; J. Storey, Studia kulturowe i badania kultury popularnej, przekł. i red. tomu J. Barański, Kraków 2003, s. 116-123.

${ }^{8}$ P. Siuda, Mechanizmy kultury prosumpcji, czyli fani i ich globalne zróżnicowanie, „Studia Socjologiczne” 2012, nr 4, s. 109-132. 
oryginale, jak zgodni są medioznawcy, z pewnością stymulują recepcję 9 Uwagi powyższe, chociaż w dużej mierze oparte na obserwacjach światowych społeczności fanowskich, w pewnym stopniu przekładają się na rodzime doświadczenia. Szczególnie obecnie, kiedy wypowiedzi znawców i pogłębione recenzje znane są tylko nielicznym, a komunikacja sieciowa sprzyja popularyzacji amatorskiej twórczości i budowaniu wspólnoty. Trend ten został dostrzeżony przez producentów popkultury doceniających potrzebę tworzenia licznych produktów skoncentrowanych wokół głównego tekstu/tematu, określanych przez Henry'ego Jenkinsa mianem opowieści transmedialnych obecnych na różnych płaszczyznach (książka, film, DVD, gry, komiksy, gadżety), których całościowy odbiór daje dopiero pełny obraz uniwersum ${ }^{10}$. Jednocześnie, jak twierdzi P. Siuda za innymi badaczami przemysłu rozrywkowego, opowiadania transmedialne i media miksy różnią się od „starych form synergii popkulturowej, w wypadku których teksty z różnych platform medialnych mogły być konsumowane/ odbierane osobno bez wpływu na rozumienie treści"11. Współczesne teksty kultury funkcjonują dzięki mediom i w mediach, zyskując takie cechy, jak: wirtualność, multimedialność, interaktywnośćc ${ }^{12}$.

Pracę zamyka dobrze skonstruowane zakończenie, w którym znalazły miejsce wnioski poparte jeszcze zestawieniami tabelarycznymi liczby publikacji i czasowemu rozkładowi obecności tematyki poświęconej bestsellerowym cyklom w wybranych tytułach prasowych oraz wykresem ruchu sieciowego wokół wybranych cykli. Znalazły tu miejsce sumarycznie zebrane wnioski z prowadzonych badań i analiz. Jak słusznie pisze autor, poza właściwościami tekstów wpisującymi się w uniwersalne cechy kultury popularnej, na pewno pewien wpływ na odbiór anglojęzycznych cykli wywarła rodzima przestrzeń kulturowa i próby odnajdywania swojskości. Jednocześnie, co podkreśla M. Rogoż, poza czynnikami kulturowymi i społecznymi u podstaw tworzenia multimedialnych bestsellerów znajdują się czynniki ekonomiczne, czemu sprzyjają procesy globalizacyjne.

${ }^{9}$ W. Godzic, Rozumieć telewizję, Kraków 2001, s. 183-185.

10 H. Jenkins, Kultura konwergencji, Warszawa 2007, s. 260.

11 P. Siuda, Mechanizmy kultury prosumpcji..., s. 119.

12 E. Chuchro, Fan fiction - uwagi o twórczości literackiej i kulturze czytelniczej dzieci i młodzieży w sieci, [w:] Po Potopie. Dziecko, książka i biblioteka w XXI wieku. Praca 
Należy przyznać, że rozprawa Michała Rogoża niewątpliwie jest jedną ze szczególnie interesujących książek ostatnio wydanych w dyscyplinie bibliologia i informatologia. Na pewno przyjęta przez autora metodologia badań recepcji i przestrzeni informacyjnej w mediach wytycza kierunek postępowania dla wielu innych badaczy zainteresowanych współczesną bibliologią i społecznym odbiorem książki w kontekście mediosfery. Niewątpliwie omawiane badania także wyraźnie sygnalizują potrzebę prowadzenia badań interdyscyplinarnych. Książka zatem może okazać się także inspirująca nie tylko dla bibliologów, ale i dla przedstawicieli innych nauk humanistycznych i społecznych zainteresowanych kulturą, szczególnie kulturą cyfrową i mediami.

\section{Bibliografia}

Chuchro Ewa, Fan fiction - uwagi o twórczości literackiej i kulturze czytelniczej dzieci i młodzieży w sieci, [w:] Po Potopie. Dziecko, książka i biblioteka w XXI wieku. Praca zbiorowa, pod red. Danuty Świerszczyńskiej-Jelonek, Grzegorza Leszczyńskiego, Michała Zająca, Warszawa 2008, s. 86-96.

Godzic Wiesław, Rozumieć telewizję, Kraków 2001.

Jenkins Henry, Kultura konwergencji, Warszawa 2007.

Jenkins Henry, Textual Poachers. Television Fans and Participatory Culture, New York 1992.

Kruk Magdalena, Fenomen popularności małego czarodzieja. Harry Potter Joanne K. Rowling i młodzi odbiorcy, [w:] Bestsellery, literatura popularna, odbiorcy, pod. red. Anny Dymmel, Lublin 2009, s. 11-28.

Krzysztofek Kazimierz, BIG DATA SOCIETY. Technologie samozapisu i samo pokazu. Ku humanistyce cyfrowej. „Kultura i Historia” [online] 2012, nr 21 [dostęp 30 września 2017]. Dostępny w World Wide Web: http://www.kulturaihistoria.umcs.lublin.pl/archives/3626.

Ksiq̨żki w życiu najmłodszych, pod red. Marioli Antczak, Agaty Walczak-Niewiadomskiej, Łódź 2015.

Rogoż Michał, Czas i przestrzeń w cyklu powieściowym Joanne K. Rowling o Harrym Potterze, „Literatura i Kultura Popularna” 2010, t. 16, s. 59-75.

zbiorowa, pod red. D. Świerszczyńskiej-Jelonek, G. Leszczyńskiego, M. Zająca, Warszawa 2008, s. 87. 
Rogoż Michał, Internet Information Space of the Polish Edition of "Histories Inedites du Petit Nicholas”, „Zagadnienia Informacji Naukowej” 2010, nr 1, s. 71-83. Rogoż Michał, Kubuś Puchatek jako bohater wielu pokoleń. Z dziejów recepcji arcydzieła Alana Aleksandra Milne'a na polskim rynku wydawniczym, [w:] Młody odbiorca w kręgu lektur pożytecznych i szkodliwych, pod red. Krystyny Heskiej-Kwaśniewicz, współpraca Sylwii Gajownik, Katowice 2012, s. 59-75. Rogoż Michał, Muminki Tove Jansson na polskim rynku wydawniczym, „Toruńskie Studia Bibliologiczne" 2011, nr 4, s. 43-67.

Sadzikowska Lucyna, Mapa współczesnych badań nad ksiq̨żkq dziecięco-młodzieżowq, [w:] Literatura dla dzieci i młodzieży, pod red. Katarzyny Tałuć, Katowice 2017, s. 360-378.

Siuda Piotr, Fanfiction - przejaw medialnych fandomów, [w:] Człowiek a media. Obserwacje - wizje - obawy, pod red. Włodzimierza Gruszczyńskiego, Anny Hebdy, Warszawa 2007, s. 143-57.

Siuda Piotr, Mechanizmy kultury prosumpcji, czyli fani i ich globalne zróżnicowanie, „Studia Socjologiczne” 2012, nr 4, s. 109-132.

\section{Book for Children and Teenagers and Media. Fantasy Bestsellers and Their Reception in the Polish Media Space}

ABSTRACT: The relationship between a contemporary book for children and teenagers and the media is now a major issue for researchers. From the perspective of bibliology, Michał Rogoż monograph Fantastycznie obecne. Anglojęzyczne bestsellerowe cykle powieściowe dla dzieci i młodzieży we współczesnej polskiej przestrzeni medialnej is included. The author analyzes popular cycles of fantasy: The Cronicles of Narnia by Clive Staples Lewis, Harry Potter by Jane K. Rowling, Twiligh saga by Stephenie Meyer, Dark Materials by Philip Pulman, Inheritance by Christopher Paolini and their reception in traditional media and the Polish language Internet. This article discusses the above monograph, presents the main theses of the author and conclusions and interpretations.

KEYWORDS: bestseller, contemporary book for children and teenagers, fantasy, Harry Potter saga, Internet, media, Poland, readership, reception, Stephenie Meyer. 